\title{
Metamorphosis of whitemouth croaker Micropogonias furnieri (Pisces, Sciaenidae)
}

\author{
Mara S. Braverman ${ }^{1,}{ }^{*}$, Daniel Brown ${ }^{1}$ and E. Marcelo Acha ${ }^{1,2}$ \\ ${ }^{1}$ Instituto Nacional de Investigación y Desarrollo Pesquero (INIDEP), Paseo Victoria Ocampo No 1, Escollera Norte, B7602HSA - \\ Mar del Plata, Argentina. ${ }^{2}$ Instituto de Investigaciones Marinas y Costeras (IIMyC), Universidad Nacional de Mar del Plata (UNMdP), \\ Consejo Nacional de Investigaciones Científicas y Técnicas (CONICET), Argentina
}

Marine and Fishery Sciences MAFIS

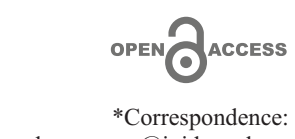

mbraverman@inidep.edu.ar

Received: 25 June 2020 Accepted: 15 September 2020

ISSN 2683-7595 (print) ISSN 2683-7951 (online)

https://ojs.inidep.edu.ar

Journal of the Instituto Nacional de Investigación y Desarrollo Pesquero (INIDEP)

This work is licensed under a Creative Commons AttributionNonCommercial-ShareAlike 4.0 International License

\begin{abstract}
Fish metamorphosis is an important ontogenetic process with a key role on early stages survival and on successful recruitment to adult populations. The whitemouth croaker (Micropogonias furnieri) is an important commercial resource for the coastal fisheries of Argentina and Uruguay. Metamorphosis was studied using morphometric and morphological analysis during larval development. Changes in morpho-meristic characters before and after metamorphosis were employed to determine the length interval of this transition by employing Principal Component Analysis. Individuals $(\mathrm{n}=430)$ from 4 to $41 \mathrm{~mm}$ standard length $(\mathrm{SL})$ were collected in the Río de la Plata estuary $\left(35.45^{\circ} \mathrm{S}, 56.35^{\circ} \mathrm{W}\right)$ in March 2006 . Length ranges of individual's developmental stages were associated with the presence of key morphological characters. During early life stages, M. furnieri changes from a big-headed, robust shape larva to a slender and more elongated body form. Most of the morphometric variables showed an inflexion point at $15.2 \mathrm{~mm} \mathrm{SL}$, with a $95 \%$ confidence interval of 14.0-16.4 mm. The anterior part of the body grows faster during early stages, probably related to an intense feeding activity strategy. The completion of pectoral fin rays and the onset of squamation determine the beginning of metamorphosis at 11-12 mm SL. At around $18 \mathrm{~mm}$ $\mathrm{SL}$, squamation ends, first barbels develop and the sagittae otoliths primordium is closed. The length-at-metamorphosis for M. furnieri was established between 9 to $18 \mathrm{~mm} \mathrm{SL}$, since all developmental characters studied highly overlapped at that interval. All those processes are indicative of the beginning of the juvenile period associated to the settlement and the start of a bottom-oriented life-style.
\end{abstract}

Key words: Sciaenidae, larvae transformation, ontogeny, morphology, morphometry.

La metamorfosis de la corvina rubia Micropogonias furnieri (Pisces, Sciaenidae)

RESUMEN. La metamorfosis de los peces es un proceso ontogenético importante con un papel clave en la supervivencia de las primeras etapas y en el reclutamiento exitoso a las poblaciones adultas. La corvina rubia (Micropogonias furnieri) es un recurso comercial importante para las pesquerías costeras de la Argentina y Uruguay. Se estudió su metamorfosis mediante análisis morfométricos y morfológicos durante el desarrollo larvario. Se utilizaron los cambios en los caracteres morfomerísticos antes y después de la metamorfosis para determinar el intervalo de duración de esta transición mediante el Análisis de Componentes Principales. Se colectaron individuos $(n=430)$ de 4 a $41 \mathrm{~mm}$ de longitud estándar (LE) en el estuario del Río de la Plata $\left(35,45^{\circ} \mathrm{S}, 56,35^{\circ} \mathrm{W}\right)$ en marzo de 2006. Los rangos de longitud de las etapas de desarrollo de los individuos se asociaron con la presencia de caracteres morfológicos clave. Durante las primeras etapas de vida, M. furnieri cambia de una larva de cabeza grande y forma robusta a una forma corporal más delgada y alargada. La mayoría de las variables morfométricas mostraron un punto de inflexión a los 15,2 mm LE, con un 
intervalo de confianza del 95\% de 14,0-16,4 mm. La parte anterior del cuerpo crece más rápidamente durante las primeras etapas, probablemente relacionada con una estrategia de actividad alimentaria intensa. La adquisición del número definitivo de radios de la aleta pectoral y el inicio de la escamación determinan el comienzo de la metamorfosis a los 11-12 mm LE. Alrededor de los $18 \mathrm{~mm}$ LE, termina la escamación, se desarrollan las primeras barbillas y se cierra el primordio de los otolitos sagittae. La longitud-de-metamorfosis para M. furnieri se estableció entre 9 y $18 \mathrm{~mm}$ LE, dado el alto grado de superposición que presentaron los caracteres de desarrollo estudiados. Todos esos procesos son indicativos del inicio del período juvenil asociado al asentamiento y al comienzo de un estilo de vida orientado hacia el fondo.

Palabras clave: Sciaenidae, transición larva-juvenil, ontogenia, morfología, morfometría.

\section{INTRODUCTION}

The way on that ontogeny of fishes proceed has been broadly discussed leading to two antagonistic visions. One states that ontogeny is a gradual process during which small and inconspicuous changes in form and structure accumulate continuously (Kováč and Copp 1999). The second view, represented by the 'theory of saltatory ontogeny' (Balon 1984), considers development as a sequence of longer stabilized steps (during which all the structures and organs develop gradually and continuously) alternating with thresholds. A threshold is a short interval where rapid changes occur from one steady state to the next. Nevertheless, early life stages of fish have been recognized by both 'gradualists' and 'saltationists' (see Kováč and Copp 1999) as being characterized by different fish capabilities, requirements, ecological interactions and growth/mortality events (e.g. Smith 1985; Koumoundouros et al. 2009; Nikolioudakis et al. 2010). The beginning of the larval period (Balon 1984) occurs when the individual is capable of feed orally, while the juvenile stage implies the disappearance of all larval characters and the appearance of nearly all the adult ones (Pavlov 1999). The transit between those periods consists on a remodeling process called 'metamorphosis' (Balon 1989), which represents an important ontogenetic event for fish with consequences for the survival of early stages and strong consequences for recruitment to adult populations (Govoni 2004).
To define the onset of the juvenile period, different approaches are traditionally used. From a functional and structural perspective, this event is associated with a change in allometric growth or shape (e.g. Copp and Kováč 1996; Sagnes et al. 1997; Kováč et al. 2006), coupled with a series of changes (abrupt or gradual) in morphological and meristic characters. Such changes are the acquisition of adult complement of fins spines and rays, adult pigmentation, onset or end of squamation, ossification of the axial skeleton and disappearance of larval characters (McCormick et al. 2002; Urho 2002; Ditty et al. 2003). From an ecological perspective, in demersal and benthic fish, metamorphosis is usually linked to settlement (Werner 2002) i.e., the ontogenetic shift by which pelagic larvae colonize benthic habitats (McCormick et al. 2002). Metamorphosis is a preparation for the colonization of a new habitat and the integration into a new trophic web, as larvae abandon the plankton to become part of the demersal-benthic communities (e.g. Secor 2015). That shift can be detected in otoliths of several fish species (Wilson and McCormick 1997, 1999) as a transition mark or 'check' (Campana and Neilson 1985). For temperate and cold water fishes, formation of accessory nuclei in their otoliths has been associated with metamorphosis and settlement processes (Sogard 1991; Morales-Nin and Aldebert 1997; Morioka et al. 2001; Buratti and Santos 2010).

Setting a threshold value as the 'length-atmetamorphosis' ( $\mathrm{L}_{\text {juv }}$ from Fuiman's ontogenetic index) is highly complex due to individual variability and ontogenetic stage of individual characters. This is why in several studies a single 
character (e.g., the onset or end of squamation, definitive fin radios acquisition, etc.) is considered, although this approach results inadequate for a precise definition of metamorphosis (Urho 2002; Ditty et al. 2003), where a series of morphological, morphometric, physiological and ethological events should converge. In that sense, Urho (2002) stated that 'the use of a single morphological trait to infer metamorphosis is as inadequate as using a single character for the identification of a species'. A clear determination of larvae-juvenile transition is particularly important to identify ontogenetic changes in the use of resources (Juanes and Conover 1994; Boglione et al. 2003). Most of the characters associated to metamorphosis undergo changes in a synchronized way (Ditty et al. 2003), suggesting the need to analyze the metamorphosis process as a holistic approach.

The whitemouth croaker, Micropogonias furnieri (Desmarest 1823), is the dominant species in terms of biomass in the Río de la Plata region and the main target of the coastal fisheries of Argentina and Uruguay, representing ca. $20 \%$ of coastal species landings in Argentina (Carozza et al. 2004). It is a demersal species with a long lifespan (up to 39 years in the region). In Argentina and Uruguay it reproduces from November to April, spawning several batches of pelagic eggs with an indeterminate annual fecundity. Main reproduction ground covers a narrow band across the inner Río de la Plata estuary between Montevideo $\left(34^{\circ} 50^{\prime} \mathrm{S}-56^{\circ} 10^{\prime} \mathrm{W}\right)$ and Punta Piedras $\left(35^{\circ} 25^{\prime} \mathrm{S}-57^{\circ} 10^{\prime} \mathrm{W}\right)$, at depths between 6 and 8 $\mathrm{m}$ (Acha et al. 1999; Carozza et al. 2004). The area is characterized by a bottom salinity front (Mianzan et al. 2001) in which whitemouth croaker eggs were only present below the halocline where salinity ranges from 9.7 to 27.3 (Acha et al. 1999). During warmest months (October through May), there is evidence of retention of whitemouth croaker larvae in the inner part of the Río de la Plata estuary. This area coincides with the location of the bottom salinity front and the maximum turbidity zone (Braverman et al. 2009). Larvae retention in this area would ensure closeness to the main nursery ground: Samborombón Bay (Mianzan et al. 2001). Early life stages of this species have been described for identification purposes with a classical approach (Sinque 1980; Weiss 1981), not intending to outline critical moments of the early life history, such as the larvae-juvenile transition. Thus, to define metamorphosis more accurately we employed a multivariate approach using morphometric and morphological analyses during larval development.

The multivariate approach consists of a morphometric analysis based on the principles of multivariate allometry described by Shea (1985) and a morpho-meristic analysis based on Ditty et al. (2003). The former studied the relationship between a group of morphometric measures and the individual's total length. The later consisted on the assignation of scores to individual characters, where the sum of them for each individual represents an index of morphological change associated to metamorphosis. Hence, the objective of this study was to investigate the larvaejuvenile transition (hereafter metamorphosis), looking for changes in morpho-meristic characters before and after the metamorphosis to determine the length interval for these changes.

\section{MATERIALS AND METHODS}

M. furnieri larvae and juveniles (less than a year-old) were collected during a scientific cruise to Río de la Plata spawning area in March 2006. A vertically stratified plankton sampling along transects perpendicular to bathymetry was performed during daylight. Samples were taken at stations separated 10-12 km at three depth levels. Water column was sampled above (or c.a. $2.5 \mathrm{~m}$ depth) and below (or c.a. $6.2 \mathrm{~m}$ depth) the halocline with a Motoda sampler equipped with a 
mechanical opening-closing device and a $200 \mu \mathrm{m}$ mesh span net. The third level was sampled by an epibenthic sledge with a $500 \mu \mathrm{m}$ mesh span net (see Braverman et al., 2009).

A total of $249 M$. furnieri individuals were identified on board and frozen for a later otoliths extraction; the rest of the samples were fixed in $4 \%$ formalin. Some specimens from the ichthyoplankton collection of the Instituto Nacional de Investigación y Desarrollo Pesquero (INIDEP) were also used to complete the length classes (n $=15$ ). Those individuals from the collection come from the same study area. An alizarin dying technique (modified from Potthoff 1984 and Taylor and Van Dyke 1985) was performed onto the specimens for a better observation of structures.

Morphometric and morphological analyses were performed on an ontogenetic series from 4 to $41 \mathrm{~mm}$ standard length (SL). For morphometric analysis, images of each individual $(\mathrm{n}=71)$ were taken using a digital camera mounted in a compound microscope. A series of measurements (Figure 1; Table 1) were taken from those images with the Axio Vision Software (Carl Zeiss). The shortening correction due to the fixation method was not considered assuming that it was similar in all measured individuals. For morphological analysis, a group of events related to the external morphology was analyzed on the ontogenetic series $(n=120)$. Development stage was determined following Moser (1996) and Fuiman and Werner (2002): larvae at pre-flexion, flexion, postflexion, in transformation and early juveniles.

Distinctive characters of each individual were registered: fin rays appearance (pectoral, anal, dorsal and pelvic); scales coverage was classified into 4 categories: (a) on the caudal peduncle, (b) from the caudal peduncle to the anus, (c) from the caudal peduncle to the head, (d) totally scaled; and presence/absence of mentonian barbels. Finally, otoliths were extracted from frozen specimens $(\mathrm{n}=85)$ using a $\mathrm{NaClO}$ solution for tissue disintegration. They were mounted in glass slides with a transparent mounting medium and polished when necessary with lapping film paper in a decreasing order of porosity $(12,9$ or $3 \mu)$ for a better visualization. Otolith development was studied by registering the occurrence of accessory nuclei and the primordium (polygonal area center-enclosed by the accessory nuclei).

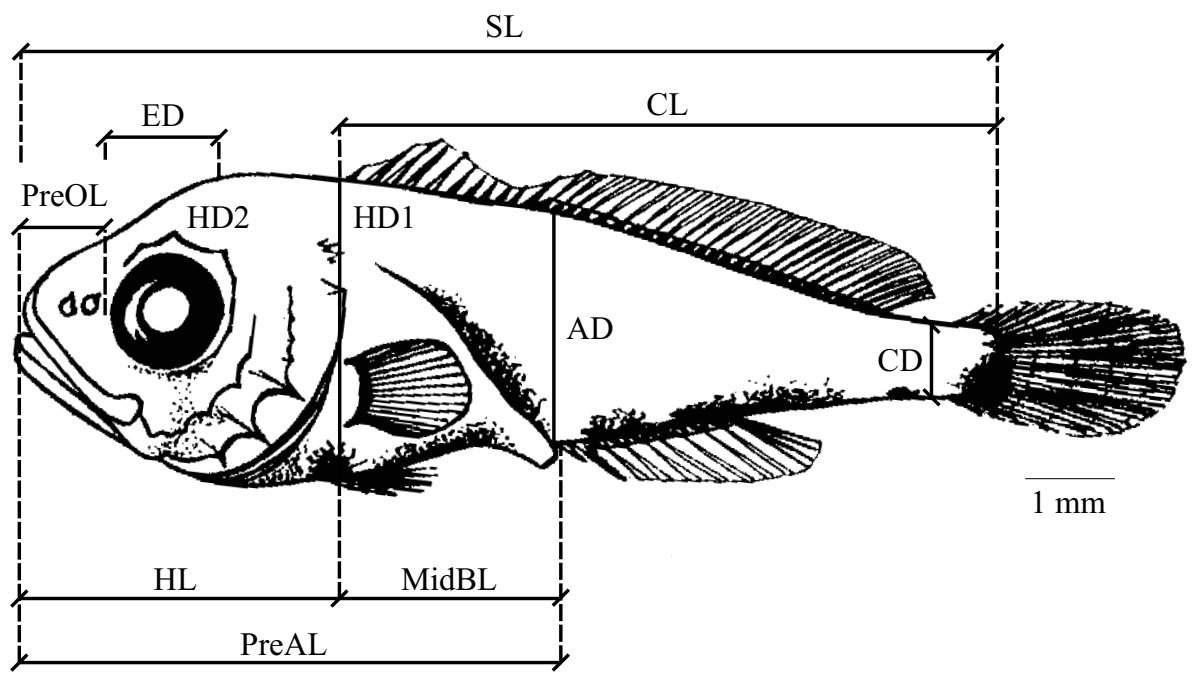

Figure 1. Morphometric measurements taken from Micropogonias furnieri individuals. SL: standard Length, ED: eye diameter, HL: head length, PreAL: pre-anal length, HD1: head depth 1, HD2: head depth 2, AD: anal depth, CD: caudal depth, Pre-OL: pre-orbital length, Mid-BL: mid-body length, CL: caudal length. Illustration taken from Weiss, 1981. 
Table 1. Description of morphometric characters measured in Micropogonias furnieri and its abbreviations (adapted from Nikolioudakis et al. 2010).

\begin{tabular}{|c|c|c|}
\hline Character & Abbreviation & Description \\
\hline Standard length & SL & From the tip of the snout to the caudal rays insertion \\
\hline Eye diameter & ED & Parallel to the longitudinal axis of the body \\
\hline Head length & HL & From the tip of the snout to the margin of the gill cover \\
\hline Pre-anal length & PreAL & From the tip of the snout to the anus \\
\hline Head depth 1 & HD1 & From the dorsal to the ventral margin of the body at the operculum \\
\hline Head depth 2 & HD2 & From the dorsal to the ventral margin of the body at the center of the eye \\
\hline Anal depth & $\mathrm{AD}$ & From the dorsal to the ventral margin of the body at the anus \\
\hline Caudal depth & $\mathrm{CD}$ & From the dorsal to the ventral margin of the body at the caudal peduncle \\
\hline Pre-orbital length & PreOL & From the tip of the snout to the anterior margin of the eye \\
\hline Mid-body length & MidBL & From the margin of the gill cover to the anus \\
\hline Caudal length & CL & From the margin of the gill cover to the insertion of the caudal fin \\
\hline
\end{tabular}

\section{Data analysis}

\section{Morphometry and bi-variate allometry}

Firstly, morphometric relationships were studied using linear regression analysis between the logarithms of each variable (morphometric measurement) versus length (SL) (Table 1). We employed standard length for post-flexion individuals and notochord length for pre-flexion and flexion specimens. Allometric growth pattern of each variable in relation to SL was studied by using the logarithmic form of the allometric growth model (Huxley 1932): $\log (Y)=\log (a)+$ $b \log (S L)$, where $Y$ is the variable examined and $b$ is the allometric coefficient. Secondly, regressions' residuals $(\mathrm{Y})$ were analyzed to identify possible allometric changes as follows: if allometric growth of the variables was constant (slope without changes) then residuals would show a random pattern; alternatively, if variables showed changes in their growth they would have a residual distribution (Y versus SL) with a specific form as it was shown by Sagnes et al. (1997), Gozlan et al. (1999) and Nikolioudakis et al. (2010).

Similarly, morphometric indexes $\left(\mathrm{I}_{\mathrm{m}}\right)$ showing representative changes in the larvae-juvenile tran- sition were analyzed. Indexes were calculated as the percentage of the morphometric variable $\left(\mathrm{V}_{\mathrm{m}}\right)$ with respect to length (SL): $\mathrm{I}_{\mathrm{m}}=\mathrm{V}_{\mathrm{m}} / \mathrm{SL} * 100$. The length at which the change in oblique orientation of $\mathrm{I}_{\mathrm{m}}$ occurred $\left(\mathrm{L}_{\mathrm{i}}\right)$ was estimated by using a piecewise linear regression fitted with a nonlinear estimation procedure: $\mathrm{I}_{\mathrm{m}}=\mathrm{b}_{0}+\mathrm{b}_{1} \mathrm{SL}+$ $\mathrm{b}_{2}\left(\mathrm{SL}-\mathrm{L}_{\mathrm{i}}\right)\left(\mathrm{SL} \geq \mathrm{L}_{\mathrm{i}}\right)$; where $b_{0}$ is the y-intercept, $b_{1}$ is the slope of the relationship of the values $\leq$ $\mathrm{L}_{\mathrm{i}}, b_{2}$ is the change in the slope $\left(b_{1}\right)$ that results in the slope when $\mathrm{SL} \geq \mathrm{L}_{\mathrm{i}}$, and $\mathrm{L}_{\mathrm{i}}$ is the length at which slope changes (Nikolioudakis et al. 2010), considered here to be related to the transformation process (end of larval period).

\section{Morphometry and multivariate approach}

To determine the length-at-metamorphosis $\left(\mathrm{L}_{\mathrm{m}}\right)$, log-transformed morphometric measurements with respect to SL using a Principal Component Analysis (PCA) with covariance matrices were studied (Jolicoeur 1963a, 1963b; Shea 1985). In a PCA of a logarithmic covariance matrix of groups of animals with different growth patterns, the first component (PC1) summarizes the variation in shape as a result of a common pattern of allometric growth; while the second component 
(PC2) and the rest summarize the variations of shape as a result of divergent growth trajectories (Shea 1985). Then, the $\mathrm{L}_{\mathrm{m}}$ at which a change in PC2 orientation occurs and the lengths of possible inflexion points $\left(\mathrm{L}_{\mathrm{i}}\right)$ were statistically estimated using a quadratic function $\mathrm{PC} 2=\mathrm{a}+\mathrm{b}(\mathrm{PC} 1)+$ $\mathrm{c}(\mathrm{PC} 1)^{2}$ of the Non-linear estimation Module of STATISTICA software v.7 2004 (StatSoft Inc.).

\section{Morphology}

Length ranges of developmental stages of $M$. furnieri were determined. These ranges were associated with the appearance/disappearance of several morphological characters (Table 2). Moreover, the pectoral fin ray's definitive number acquisition was analyzed with respect to length (pectoral fin tends to be the last one in acquiring the whole set of rays (Urho 2002)). Then, the squamation process was described. For morpho-meristic analysis, each specimen was scored for a suite of characters where each score represented a discrete ontogenetic event or a character stage of development (Table 2). Every character had equal weight, i.e. three possible states 0,1 and 2. The sum of character scores of each individual as an index of overall change in morphology associated with metamorphosis was calculated and expressed as percentage of the maximum total score. Total scores for the character set were analyzed with respect to length classes performing a cluster analysis with complete linkage, and to the Manhattan (city-block) distances method (Ditty et al. 2003). Finally, the length at which $50 \%$ of morphological change occurs $\left(\mathrm{L}_{50}\right)$ was obtained from the relationship between the accumulative scores percentage $(\mathrm{P})$ and SL described by the logistic function: $\mathrm{P}$ $=100 /\left(1+\exp \left(-\mathrm{a}^{*}(\mathrm{SL}-\mathrm{b})\right)\right)$. Length at which $\mathrm{P}$ $=100 \%$ constitutes the juvenile stage length.

\section{RESULTS}

\section{Developmental morphometry}

Residual distribution of each log-transformed variable fitted against SL with an allometric function showed different responses (see Appendix). With few exceptions (ED and MidBL, Figure 1; Table 1), residuals revealed a non-random distribution indicating changes in the relative growth of morphometric variables evidenced by inflexion points in the distribution of morphometric indexes (Figure 2). Thus, ED grew isometrically while MidBL showed a positive allometry in the entire

Table 2. Scores assigned to each Micropogonias furnieri individual according to the developmental stage of considered characters. The scoring of rays was performed separately for each fin (pectoral, anal, dorsal and pelvic).

\begin{tabular}{lclc}
\hline Character & Score & \multicolumn{1}{c}{ Observed pattern } & Length ranges (mm SL) \\
\hline Scales cover & 0 & No scales & $4-10$ \\
& 1 & Scales do not cover the entire body & $10.1-16.9$ \\
Fin rays & 2 & Scales covering the entire body, including head & $18-34$ \\
& 0 & No rays & $4-6.3$ \\
Otolith development & 1 & Rays in formation & $6.7-11.9$ \\
& 2 & Definitive rays & $12-34$ \\
& 0 & No accesory nuclei & $4-10.9$ \\
& 1 & Accesory nuclei not closing the primordium & $6.8-17$ \\
& 2 & Closed primodium & $15-34.9$ \\
\hline
\end{tabular}



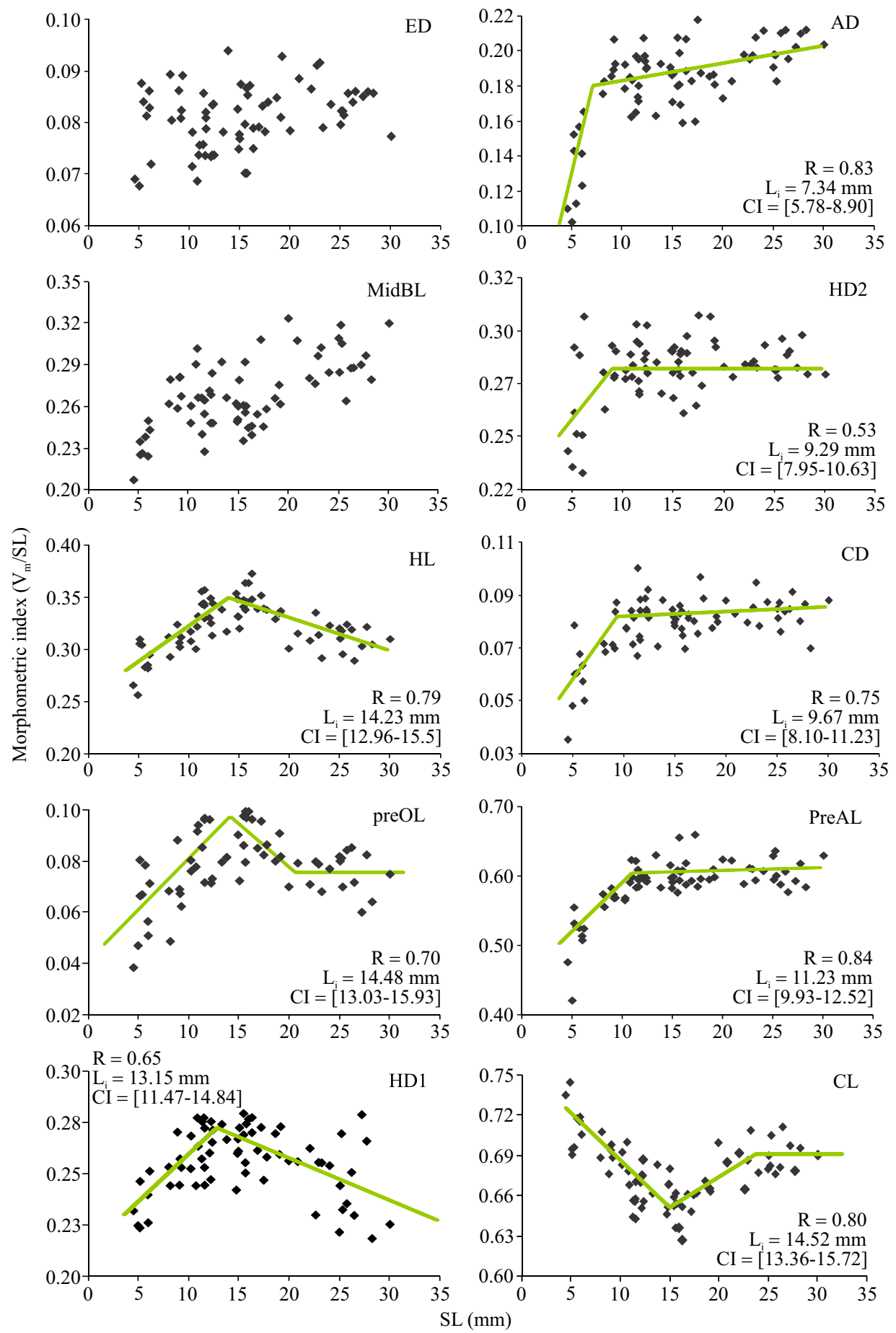

Figure 2. Relationships of morphometric indexes with standard length (SL) of individuals. Fitted lines came from non-linear regressions used to determine inflexion lengths $\left(\mathrm{L}_{\mathrm{i}}\right)$. CI: $95 \%$ confidence interval for $\mathrm{L}_{\mathrm{i}}, \mathrm{V}_{\mathrm{m}}$ : morphometric variable. Abbreviations as in Figure 1. 
length range. In turn, HL, PreOL and HD1 grew faster than SL (positive allometry) to a maximum and then got slower (negative allometry), while CL showed an opposite pattern growing slower than SL until a minimum value when it started to grew faster. In addition, variables related with body depth (HD2, AD, CD) and PreAL grew faster than SL to a point where they remained constant (or slightly grew). Inflexion points $\left(\mathrm{L}_{\mathrm{i}}\right)$ and their confidence intervals were determined by non-linear regressions of each variable (expressed as the $I_{m}$ ) with respect to SL (Figure 2).

Principal Components Analysis (Table 3) of log-transformed morphometric measurements using the covariance matrix revealed an important change in the oblique orientation of PC2 values of transformed variables when plotted against PC1 or SL (Figure 3). A highly significant quadratic relationship $(\mathrm{R}=0.62, \mathrm{p}<0.001)$ allowed to determine an $\mathrm{L}_{\mathrm{m}}=15.18 \mathrm{~mm}$ SL [CI $=14.01-16.37]$. When residuals of allometric regressions were separately examined for indi- viduals $<15.18 \mathrm{~mm} \mathrm{SL}$ and $\geq 15.18 \mathrm{~mm} \mathrm{SL}$, we observed they were randomly distributed. Because no pattern or structure were shown, it could be assumed that bi-variate allometric equations were appropriate to describe relative growth of individuals before $\left(\mathrm{SL}<\mathrm{L}_{\mathrm{m}}\right)$ or after $\left(\mathrm{SL} \geq \mathrm{L}_{\mathrm{m}}\right)$ the metamorphosis length.

\section{Morphological events}

The end of post-flexion stage and the beginning of the transition to juvenile (metamorphosis) was determined considering the completion of pectoral fin rays and the onset of squamation process, which occurred at $11 \mathrm{~mm}$ SL and $12 \mathrm{~mm} \mathrm{SL}$, respectively (Table 4; Figure 4 A: arrows 3 and 4). Meanwhile, at $c a .18 \mathrm{~mm}$ SL barbels' appearance and the end of squamation process established the end of metamorphosis according to morphological events (Figure 4 A: arrows 5 and 6).

First pectoral rays appeared between 5 to $7 \mathrm{~mm}$ $\mathrm{SL}$ and the fin rapidly completed its rays at $12 \mathrm{~mm}$

Table 3. Principal Component results of the first (PC1) and second factor (PC2) for the log-transformed morphometric characters studied (abbreviations in Table 1).

\begin{tabular}{|c|c|c|c|c|c|c|c|c|}
\hline \multirow[b]{2}{*}{$\begin{array}{l}\text { Morphometirc } \\
\text { character }\end{array}$} & \multicolumn{2}{|c|}{$\begin{array}{l}\text { Eigenvectors } \\
\text { coefficients }\end{array}$} & \multicolumn{2}{|c|}{$\begin{array}{l}\text { Factor score } \\
\text { correlations }\end{array}$} & \multicolumn{2}{|c|}{ Factor-variable } & \multirow[b]{2}{*}{ Eigenvalues } & \multirow[b]{2}{*}{$\begin{array}{l}\% \text { total } \\
\text { variance }\end{array}$} \\
\hline & PC1 & $\mathrm{PC} 2$ & PC1 & PC2 & $\mathrm{PC} 1$ & PC2 & & \\
\hline SL & -0.275 & 0.163 & -0.357 & 1.955 & -0.996 & 0.063 & 0.595 & 97.872 \\
\hline ED & -0.284 & 0.284 & -0.369 & 3.412 & -0.986 & 0.106 & 0.007 & 1.137 \\
\hline PreAL & -0.305 & 0.048 & -0.396 & 0.574 & -0.998 & 0.017 & 0.002 & 0.385 \\
\hline HL & -0.292 & -0.126 & -0.379 & -1.516 & -0.995 & -0.046 & 0.001 & 0.194 \\
\hline HD1 & -0.291 & 0.075 & -0.377 & 0.897 & -0.997 & 0.028 & 0.001 & 0.155 \\
\hline $\mathrm{AD}$ & -0.339 & 0.063 & -0.349 & -1.474 & -0.992 & 0.020 & 0.001 & 0.101 \\
\hline $\mathrm{CD}$ & -0.340 & -0.056 & -0.440 & 0.762 & -0.990 & -0.018 & 0.000 & 0.068 \\
\hline PreOL & -0.324 & -0.821 & -0.441 & -0.674 & -0.963 & -0.264 & 0.000 & 0.058 \\
\hline HD2 & -0.269 & -0.123 & -0.419 & -9.876 & -0.993 & -0.049 & 0.000 & 0.030 \\
\hline MidBL & -0.317 & 0.289 & -0.411 & 3.478 & -0.990 & 0.097 & 0.000 & 0.001 \\
\hline CL & -0.268 & 0.298 & -0.347 & 3.579 & -0.990 & 0.119 & 0.000 & 0.000 \\
\hline
\end{tabular}




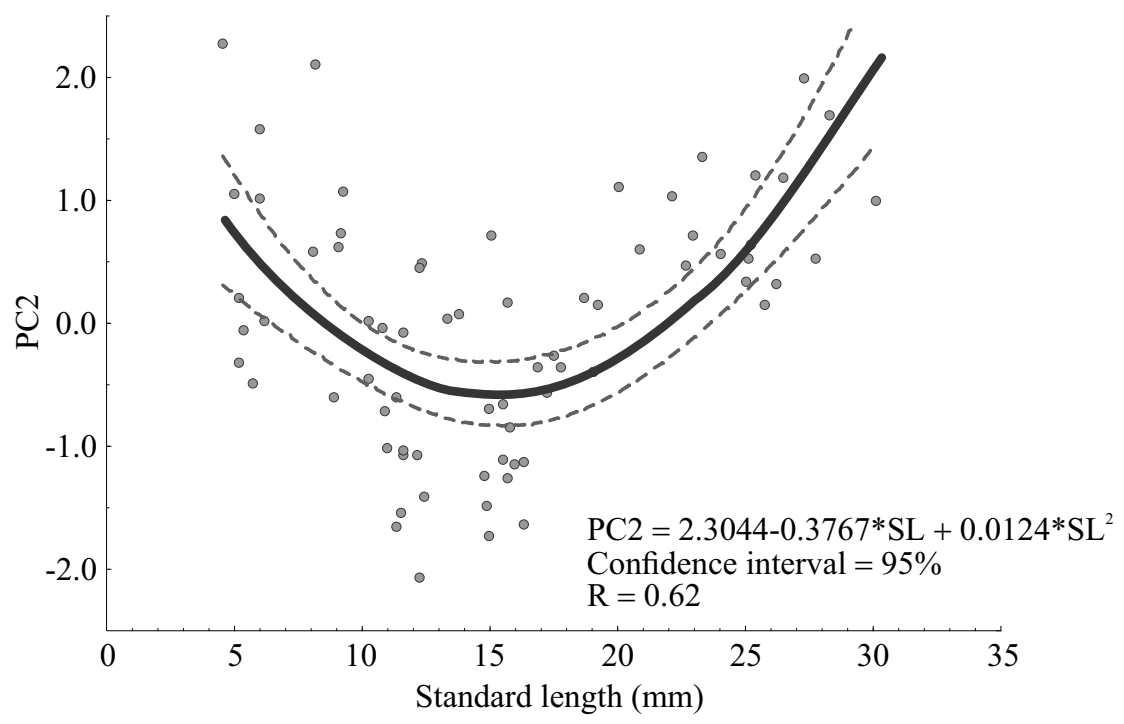

Figure 3. Multivariate analysis (PCA) showing the relation between SL (representing PC1) and PC2, and the quadratic fit (lines) assessed for the length-at-metamorphosis $\left(\mathrm{L}_{\mathrm{m}}\right)$. Dashed lines represent $95 \%$ of confidence.

Table 4. Length intervals of developmental stages of Micropogonias furnieri. Transition length was calculated as the mean value between the highest value of a stage and the lowest value of the previous stage.

\begin{tabular}{lccccc}
\hline & & \multicolumn{3}{c}{ Length (mm SL) } \\
\cline { 3 - 5 } Stage & N & Min & Max & Transition \\
\hline Pre-flexion & 19 & - & 6.2 & \rangle & 5.6 \\
Flexion & 26 & 4.9 & 8.4 & \rangle & 7.4 \\
Post-flexion & 26 & 6.4 & 11.3 & \rangle & 11.5 \\
Transformation & 32 & 11.7 & 19.2 & \rangle & 18.6 \\
Juvenile & 17 & 18 & - & & \\
\hline
\end{tabular}

SL (Figure 4 B). Squamation occurred in the transformation stage in a posterior-anterior direction (Figure 5). First scales appeared in the caudal peduncle separated from each other. Its morphology was rather simple: oval-shaped, with smooth edges and a few concentric rings (Figure 5.1). As squamation process progressed, scales morphology became more complex developing projections in its posterior margin (ctenii) and scallops in the anterior margin, and starting to overlap each other (Figure 5.3). The head was the last part to be covered (Figure 5.2).

Cluster analysis over the scores of morphological characters defined two main groups at a distance of 50\% approximately (Figure 6 A); a group of small larvae from 4 to $9 \mathrm{~mm} \mathrm{SL}$, and a group of individuals larger than $9 \mathrm{~mm}$ SL. From the later, individuals bigger than $16 \mathrm{~mm}$ SL were grouped in an approximate distance of $15 \%$, remaining an intermediate interval from $9-16 \mathrm{~mm}$ SL of non-homogeneous groups. On the other hand, cumulative scores showed a highly significant fit $(\mathrm{R}=0.9845 ; \mathrm{p}<0.001)$ to a logistic function with $\mathrm{L}_{50}=9.24 \mathrm{~mm}$ SL (Figure $6 \mathrm{~B}$ ) and fully metamorphosed individuals larger than 18$20 \mathrm{~mm}$ SL.

\section{DISCUSSION}

Throughout the early life history, $M$. furnieri changed from a larval big-headed and robust shape to a slender and more elongated body 
A

5

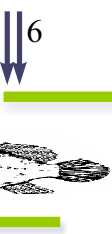

Transformation
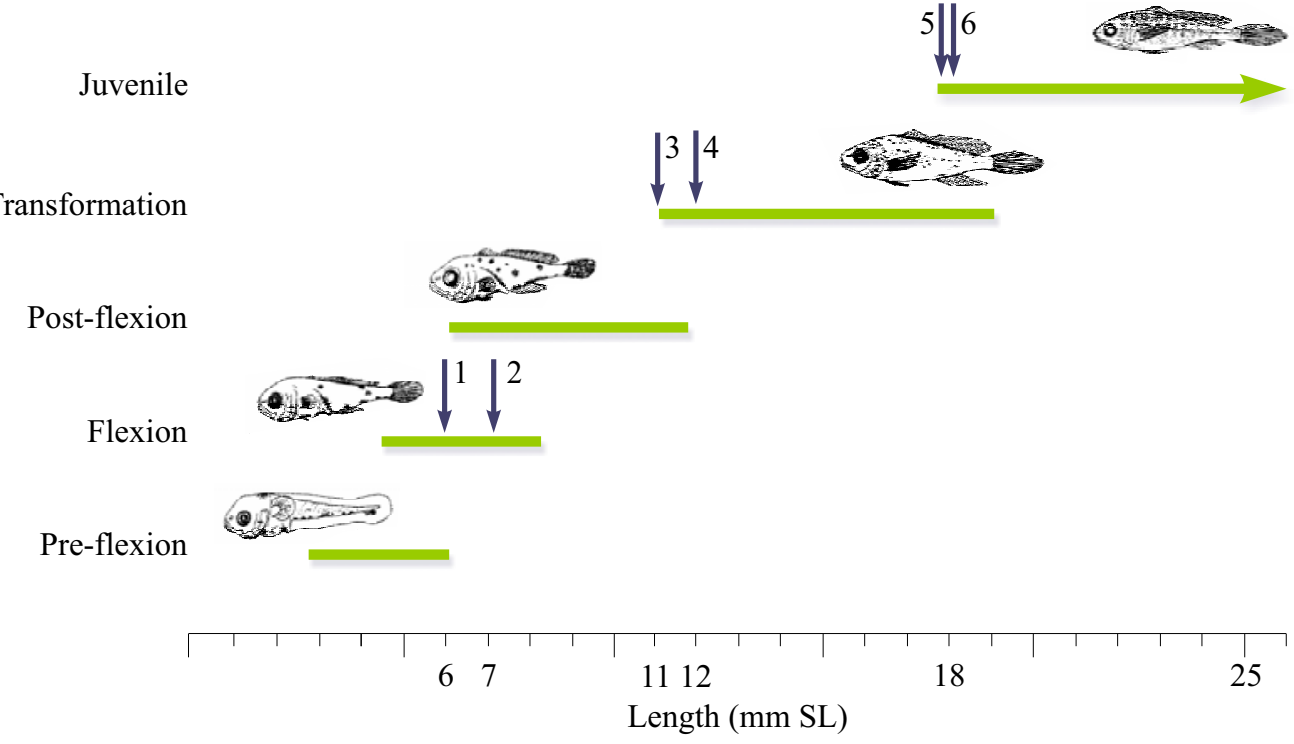

B

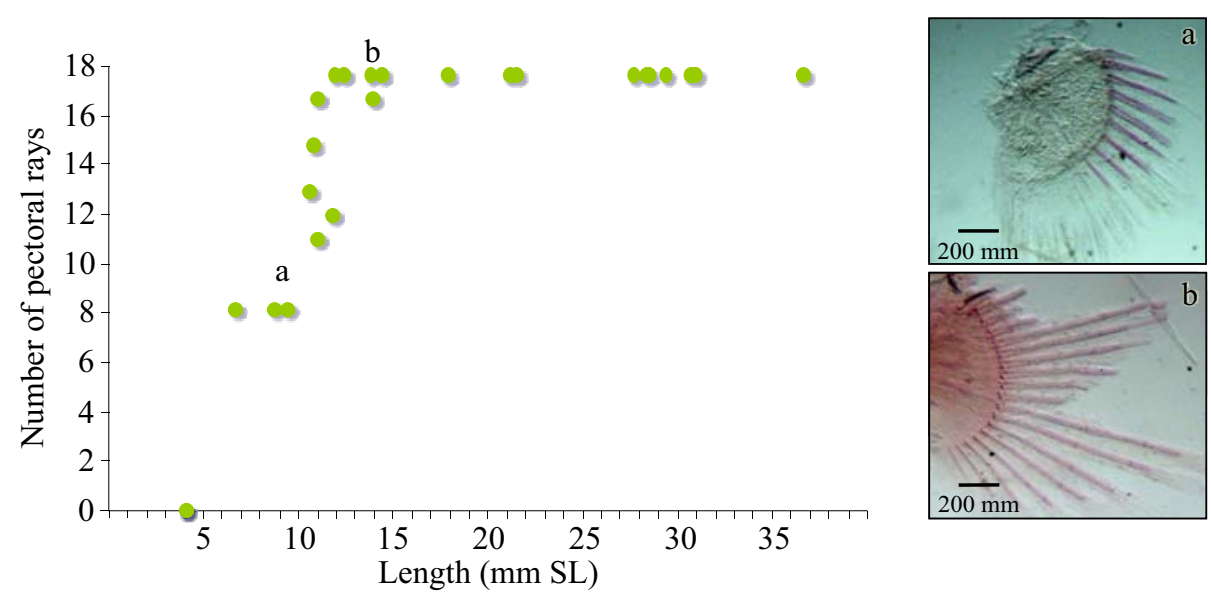

Figure 4. Summary of morphological events occurred throughout Micropogonias furnieri early ontogeny. A) Scheme of length intervals per stage. Arrows show important events: 1- caudal, dorsal and anal fins occurrence (rays in formation), 2- pelvic fin appearance, 3- onset of squamation, 4- pectoral fin definitive set of rays, 5- barbels occurrence, 6- ending of squamation process (scales in the head). B) Development of pectoral fins: a- rays in formation, b- definitive set of rays. Illustrations taken from Weiss, 1981.

shape. Most of the morphometric variables showed an inflexion point in their development and the compound analysis showed an inflexion length of $15.2 \mathrm{~mm} \mathrm{SL} \mathrm{[CI}=14-16.4]$. Multivariate morphometric analysis (PCA) indicated a change in the allometric growth of ontogenetic series evidenced by a change in the slope orientation of the PC2 versus PC1 (or SL) as stated by
Shea (1985). Relative changes in the growth of whitemouth croaker were seen in the residuals of allometric relations as well as in the estimated $\mathrm{L}_{\mathrm{m}}$, resulting in a random distribution of residuals of the two size groups detected (i.e., $\mathrm{SL}<\mathrm{L}_{\mathrm{m}}$ and $\mathrm{SL}>\mathrm{L}_{\mathrm{m}}$ ). These results constitute a valid estimation of the length-at-metamorphosis from a morphometric point of view. 

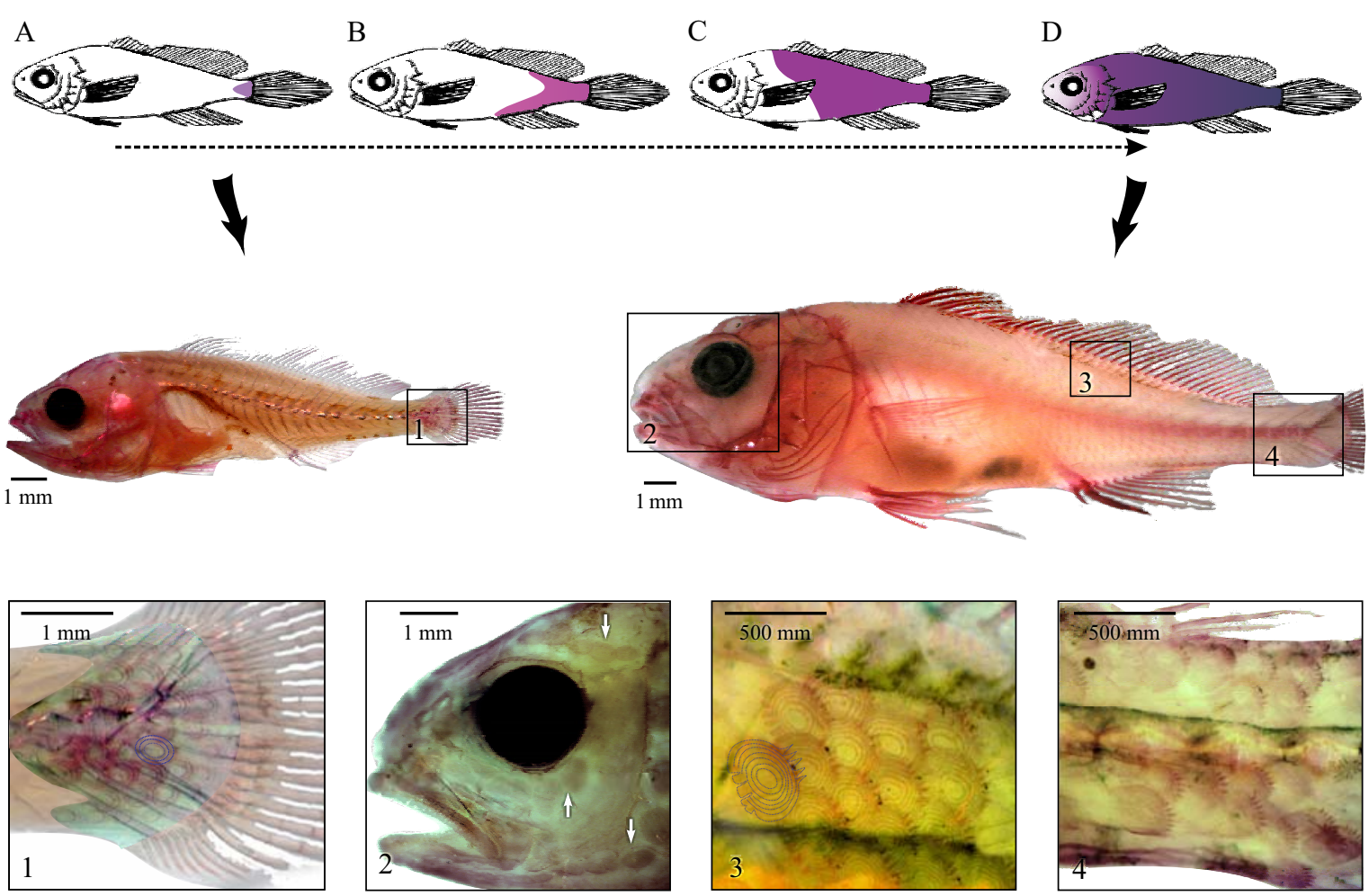

Figure 5. Sequence of squamation (A-D) observed in Micropogonias furnieri. Different colors indicate degree of squamation, from lesser (A) to greater (D) complexity. Boxes 1-4: details of coverage and complexity of scales throughout the body. White arrows indicate scales position. Box 3: scheme of a scale.

Two well-defined groups were found in the scoring analysis (morphology): one with individuals $<9 \mathrm{~mm}$ SL and other with individuals $>16 \mathrm{~mm} \mathrm{SL}$, matching the length at which 50\% and $100 \%$ of the body shape change occurs $\left(\mathrm{L}_{50}\right.$ $=9.2 \mathrm{~mm} \mathrm{SL}$ and $\mathrm{L}_{100}=17 \mathrm{~mm} \mathrm{SL}$, respectively). Individuals between 9 to $16 \mathrm{~mm}$ SL did not form a homogeneous group probably due to they were undergoing a shape transition. In accordance to Weiss (1981), morpho-meristic analysis during this length interval showed the definitive pectoral ray's acquisition and the onset of squamation at $11 \mathrm{~mm}$ and $12 \mathrm{~mm} \mathrm{SL}$, respectively. These events occurred close to the appearance of accessory nuclei in the otoliths (Braverman et al. 2015), coincidently with the change in body proportions. Finally, squamation ended at $18 \mathrm{~mm}$ SL approximately, when first barbels appeared and the otolith primordium was closed (c.a. $16 \mathrm{~mm} \mathrm{SL}$, Braverman et al. 2015).

Early in larval development, variables related to the head showed a higher relative growth rate than the rest of the body. A higher growth of the anterior part of the body during the first ontogenetic stages has been related to feeding (Fuiman 1983; Osse et al. 1997), because an early development and differentiation of nervous (brain), sensorial (neuromasts, photoreceptors and olfactory receptors) and digestive (mandible structures) systems would contribute to improve prey detection and capture. Fin formation would increase swimming efficiency and the appearance of barbel during metamorphosis would constitute an important character helping juveniles to colonize a new habitat (settlement) and start a bottomoriented lifestyle. 

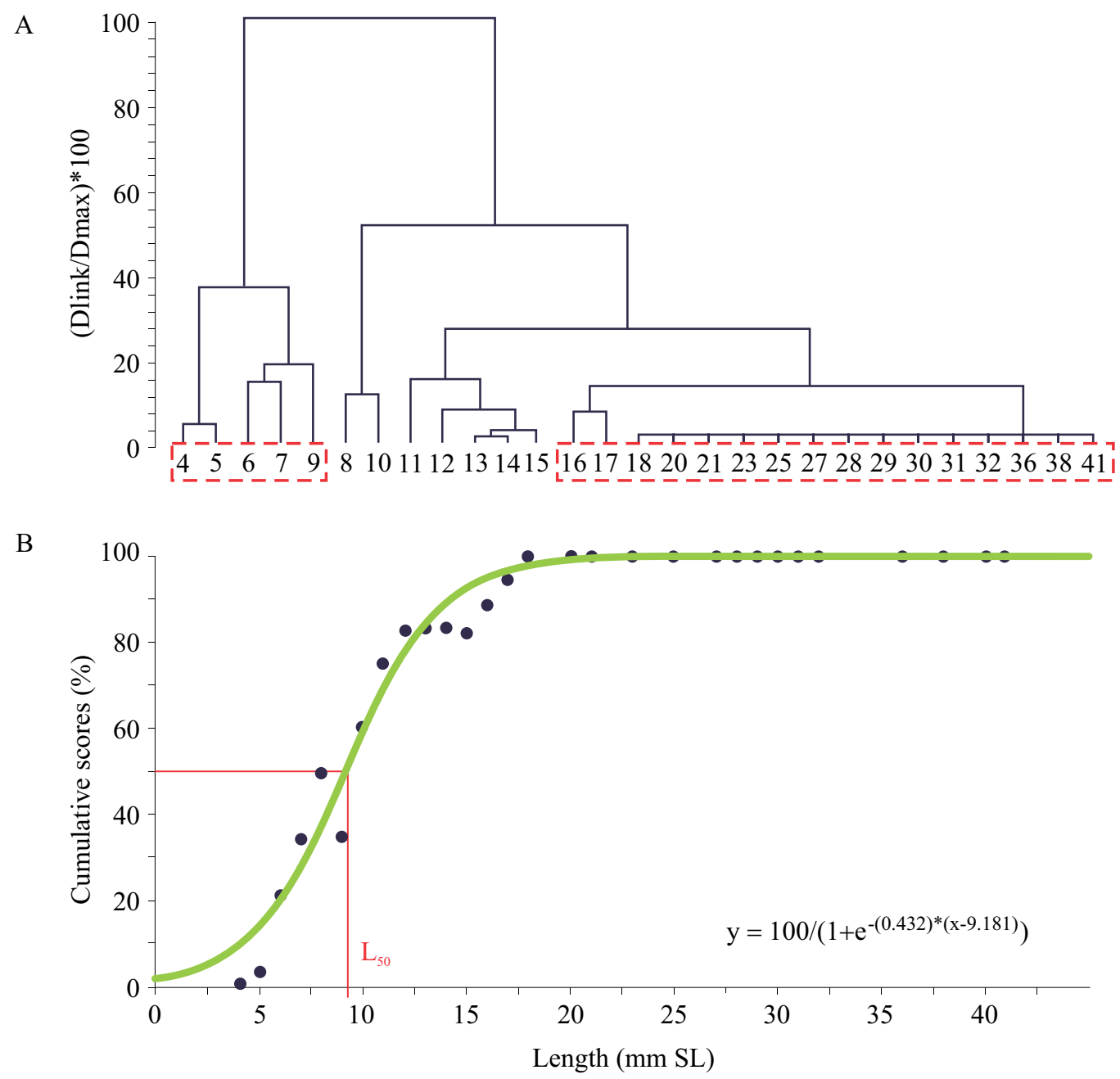

Figure 6. Morphological analysis of Micropogonias furnieri ontogenetic development. A) Cluster analysis of morphological characters based on Manhattan distances' method (City-Block) with complete linkage. B) Logistic graph and function with cumulative scores of characters with respect to length.

In terms of body height and pre-anal length, larvae changed their growth rate at smaller lengths (9-11 mm SL) while the head and the rest of the body showed an opposite pattern changing their growth rates at larger lengths (13-15 mm SL). We suggest that as the head reduces its relative growth the rest of the body has to grow faster to maintain proportions. Our findings could indicate a sequence of growth for these stages of development, giving priority first to the feeding function and then to locomotion and predators escape instead of digestive system development (Osse and van den Boogaart 1995). This could be possible because of the high digestibility of croaker larvae's prey (tintinnids, copepod nauplii and small copepods, Rodríguez-Graña et al. 2018) and the powerful digestive enzymes of fish larvae as shown in herring Clupea harengus (Pedersen et al. 1987). Moreover, it has been suggested that fish larvae can utilize exogenous enzymes from their prey to improve digestion (Lauff and Hoffer 1984; Kolkovski et al. 1993). 
The squamation process in demersal species has been considered an indicator of transformation between larval and juvenile stages (Miller et al. 2003), along with the process of primordium formation in otoliths, with drastic changes in early life history of fish as observed in Trachurus japonicus (Xie et al. 2005) and Merluccius hubbsi (Buratti and Santos 2010). Similar results were reported in blennids (Ditty et al. 2003), considering a group of morphological characters in which the ontogenetic development of different structures seemed to overlap during metamorphosis (see also Kanou et al. 2004; Nikolioudakis et al. 2010). Those findings are consistent with the high level of synchronization achieved in certain ontogenetic thresholds (Balon 1984) to get to the next step in development (e.g., from larval to juvenile period) (Kováč 2002). Differences in timing and developmental rates of individual characters make difficult the recognition of thresholds that could be in the root of the 'saltationist-gradualist' debate (Kováč and Copp 1999). Hence, multivariate approach performed in our study helps to a better identification of thresholds based on the degree of coincidence of changing variables.

Multivariate approach showed that developmental characters studied on the whitemouth croaker highly overlapped, even though morphological or morphometric characters could begin the transformation at different ontogenetic times (lengths, sensu Fuiman et al. 1998) and at different speeds. Although not all the inflexion points were detected at the same size, 10 morphometric measurements demonstrated significant changes in relative growth within a length interval similar to that found in the study of morphological events. Considering all the events together, it is strongly suggested a developmental interval of 9 to $18 \mathrm{~mm} \mathrm{LS}$ as the moment of greatest change in body shape, i.e., metamorphosis.

Most marine fishes tend to spawn at specific times and places within predictable and distinctive circulation features. The most common life history of fishes that use estuaries involves spawning of planktonic eggs at sea and the subsequent recruitment to estuaries as post-larvae or juveniles. Due to the net seaward movement of estuarine waters, the export of early life-history stages from estuaries has been argued to be a major problem for estuarine spawners (Boehlert and Mundy 1988), and the lack of retention mechanisms has been proposed to explain why fishes do not typically spawn inside estuaries (e.g., Dando 1984; Haedrich 1992). Unlike most estuaries, spawning activity is rather common in the Río de la Plata, in which the existence of retention mechanisms has been proposed (Acha et al. 1999; Simionato et al. 2008; Braverman et al. 2009). This estuary is very shallow and essentially dominated by the wind. Retention process is a consequence of the estuarine response to natural wind variability at the scale of 3-5 days acting over bathymetric features (Simionato et al. 2008). Moreover, river discharge fluctuations modulate retention variability at interannual scales (Acha et al. 2008). Whitemouth croakers spawn well inside the estuary at the bottom salinity/turbidity front (Macchi and Christiansen 1996; Acha et al. 1999), where their larvae remain retained (Braverman et al. 2009). Retention is by no manner a $100 \%$ effective mechanism and recruitment success of $M$. furnieri shows strong fluctuations that would be linked to the dynamics of the estuarine waters (Acha et al. 2008). For many marine fishes habitat shifts often occur at metamorphosis when larvae undergoes a striking change from a pelagic, planktonic organism, to a demersal one (Werner 2002). This seems to be the case with M. furnieri, whose smaller larvae $(<10 \mathrm{~mm} \mathrm{SL})$ appear at the whole water column but larger sizes ( $>10 \mathrm{~mm}$ SL) probably undergo the settlement process inhabiting near the bottom (Braverman et al. 2009).

During settlement, larvae and young juveniles move from pelagic to demersal food webs with attendant changes to their foraging success and predation risk. However, settlement means not only the encounter of a new array of prey and 
predators, it also means a shift from a pelagic and more dispersive stage to a demersal and more sedentary one (Secor 2015). Retention would improve when larvae or early juveniles remain in the bottom boundary layer (Mann and Lazier 1996), in this way settled croakers would diminish their chances of being exported from the estuary. A fast metamorphosis and successful settlement could enhance survival, and consequently improving recruitment. So identifying the processes that allow juveniles to attain retention inside adequate habitats is important to effectively understand marine species population dynamics.

\section{ACKNOWLEDGEMENTS}

We are grateful to Dr Daniela Alemany and to Dr Marina Diaz for their support and useful comments on the manuscript. We also thank the reviewers for their valuable suggestions that helped us to improve the quality of our original manuscript. This study was supported by Agencia PICT 2003 no 07-13659; CONICET PIP 2009, Universidad Nacional de Mar del Plata EXA $355 / 06$ and by a grant from the Inter-American Institute for Global Change Research (IAI) CRN 2076 sponsored by the US National Science Foundation (Grant GEO-0452325). This is an INIDEP contribution no 2143.

\section{REFERENCES}

Acha EM, Mianzan HW, Guerrero RA, CarReto J, Giberto D, Montoya N, Carignan M. 2008. An overview of physical and ecological processes in the Río de la Plata Estuary. Cont Shelf Res. 28: 1579-1588.

Acha EM, Mianzan HW, Lasta CA, Guerrero RA. 1999. Estuarine spawning of the whitemouth croaker Micropogonias furnieri in the
Río de la Plata, Argentina. Mar Freshwater Res. 50: 57-65.

BALON EK. 1984. Reflections on some decisive events in the early life of fishes. Trans Am Fish Soc. 113: 178-185.

BALON EK. 1989. The Tao of life: from the dynamic unity of polar opposites to self-organization. In: BRUTON MN, editor. Alternative life-history styles of animals. Perspectives in vertebrate science. Vol. 6. Dordrecht: Kluwer Academic Publishers. p. 7-40.

Boenlert GW, Mundy BC. 1988. Roles of behavioral and physical factors in larval and juveniles fish recruitment to estuarine nursery areas. Am Fish Soc Symp. 3: 51-67.

Boglione C, Giganti M, Selmo C, Cataudella S. 2003. Morphoecology in larval fin-fish: a new candidate species for aquaculture, Diplodus puntazzo (Sparidae). Aquacult Int. 11: 1741.

Braverman MS, ACHA EM, Gagliardini DA, Rivarossa M. 2009. Distribution of whitemouth croaker (Micropogonias furnieri, Desmarest 1823) larvae in the Río de la Plata estuarine front. Estuar Coast Shelf Sci. 82: 557565.

Braverman M, Brown DR, ACHa EM. 2015. Indirect validation of daily increments in whitemouth croaker (Micropogonias furnieri) larvae otoliths. Rev Invest Desarr Pesq. 26: 59-67.

Buratti CC, Santos BA. 2010. Otolith microstructure and pelagic larval duration in two stocks of the Argentine hake, Merluccius hubbsi. Fish Res. 106: 2-7.

Campana SE, Nielson JD. 1985. Microstructure of fish otoliths. Can J Fish Aquat Sci. 42: 1014-1032.

Carozza CR, Lasta CA, Ruarte C, Cotrina CP, Mianzan H, ACHA EM. 2004. Corvina rubia (Micropogonias furnieri). In: SÁNCHEZ RP, BezzI SI, editors. El Mar Argentino y sus recursos pesqueros. Tomo 4. Los peces marinos de interés pesquero. Caracterización 
biológica y evaluación del estado de explotación. Mar del Plata: Instituto Nacional de Investigación y Desarrollo Pesquero (INIDEP). p. 255-270.

Copp GH, KovÁČ V. 1996. When do fish with indirect development become juveniles? Can J Fish Aquat Sci. 53: 746-752.

DANDO PR. 1984. Reproduction in estuarine fish. In: Potts GW, Wootton RJ, editors. Fish reproduction: strategies and tactics. London: Academic Press. p. 155-170.

DitTy JG, Fuiman LA, Shaw RF. 2003. Characterizing natural intervals of development in fishes: an example using blennies (Teleostei: Blenniidae). In: The big fish bang. Proceedings of the 26th annual larval fish conference. Bergen. p. 405-418.

FUIMAN LA. 1983. Growth gradients in fish larvae. J. Fish Biol. 23: 117-123.

Fuiman LA, Poling KR, Higgs DM. 1998. Quantifying developmental progress for comparative studies of larval fishes. Copeia. 3: 602611.

FuimAn LA, WeRnER RG. 2002. Fishery science: the unique contributions of early life stages. Oxford: Blackwell Science Ltd. Osney Mead. $326 \mathrm{p}$.

Govoni JJ. 2004. The development of form and function in fishes and the question of larval adaptation. Am Fish Soc Symp. 40: 1-7.

Gozlan RE, Copp GH, TourenQ JN. 1999. Comparison of growth plasticity in the laboratory and field, and implications for the onset of juvenile development in sofie, Chondrostoma toxostoma. Environ Biol Fish. 56: 153-165.

HAEDRICH RL. 1992. Estuarine fishes. In: Ketchum BH, editor. Ecosystems of the world. Estuaries and enclosed seas. Vol 26. Amsterdam: Elsevier. p. 185-207.

HuXLeY J. 1932. Problems of relative growth. New York: New York Dial Press.

JolicoeUR P. 1963a. The multivariate generalization of the allometry equation. Biometrics. 19: 497-499.
JoLiCOEuR P. 1963b. The degree of generality of robustness in Martes americana. Growth. 27: $1-27$.

JuAnes F, Conover DO. 1994. Rapid growth, high feeding rates, and early piscivory in young-of-the-year bluefish (Pomatomus saltatrix). Can J Fish Aquat Sci. 51: 1752-1761.

Kanou K, Kohno H, Sano M. 2004. Morphological and functional development of characters associated with settlement in the yellowfin goby, Acanthogobius flavimanus. Ichthyol Res. 51: 213-221.

Kolkovski S, Tandler A, Kissil GW, Gertler A. 1993. The effect of dietary exogenous digestive enzymes on ingestion, assimilation, growth and survival of gilthead seabream (Sparus aurata, Sparidae, Linnaeus) larvae. Fish Physiol Biochem. 12: 203-209.

Koumoundouros G, Ashton C, Xenikoudakis G, Giopanou I, Georgakopoulou E, StickLAND N. 2009. Ontogenetic differentiation of swimming performance in Gilthead seabream (Sparus aurata, Linnaeus 1758) during metamorphosis. J Exp Mar Biol Ecol. 370: 75-81.

KovÁČ V. 2002. Synchrony and heterochrony in ontogeny (of fish). J Theor Biol. 217: 499-507.

Kováč V, Copp GH. 1999. Prelude: looking at early development in fishes. Environ Biol Fish. 56: 7-14.

Kováč V, Katina S, Copp GH, SiRyova S. 2006. Ontogenetic variability in external morphology and microhabitat use of spirlin Alburnoides bipunctatus from the River Rudava (Danube catchment). J Fish Biol. 68: 1257-1270.

Lauff M, Hoffer R. 1984. Proteolytic enzymes in fish development and the importance of dietary enzymes. Aquaculture. 37: 335-346.

Macchi GJ, Christiansen HE. 1996. Análisis temporal del proceso de maduración y determinación de la incidencia de atresias en la corvina rubia (Micropogonias furnieri). Frente Marit. 16: 93-101.

MANN KH, LAZIER JRN. 1996. Dynamics of marine ecosystems: biological-physical inter- 
actions in the oceans. Malden: Blackwell Science. 394 p.

McCormick Mi, Makey L, Dufour V. 2002. Comparative study of metamorphosis in tropical reef fishes. Mar Biol. 141: 841-853.

Mianzan H, Lasta C, Acha EM, Guerrero R, Macchi GJ, Bremec C. 2001. The Río de la Plata Estuary, Argentina-Uruguay. In: SEELIGER U, KJERFVE B, editors. Ecological studies. Coastal marine ecosystems of Latin America. Berlin: Springer-Verlag. p. 185-204.

Miller MJ, Nemerson DM, Able KW. 2003. Seasonal distribution, abundance, and growth of young-of-the-year Atlantic croaker (Micropogonias undulatus) in Delaware Bay and adjacent marshes. Fish Bull. 101 (1): 100-115.

Morales-Nin B, AldeBert Y. 1997. Growth of juvenile Merluccius merluccius in the Gulf of Lions (NW Mediterranean) based on otolith microstructure and length-frequency analysis. Fish Res. 30 (1-2): 77-85.

Morioka S, Machinandiarena L, Villarino MF. 2001. Preliminary information on internal structures of otoliths and growth of ling, Genypterus blacodes (Ophidiidae), larvae and juveniles collected off Argentina. Bull Japan Soc Fish Ocean. 65 (2): 59-66.

Moser HG. 1996. Principles and terminology. The early stages of fishes in the California current region. California cooperative oceanic fisheries investigations. Atlas. 33. p. 27-44.

Nikolioudakis N, Koumoundouros G, KiparisSIS S, Somarakis S. 2010. Defining length-atmetamorphosis in fishes: a multi-character approach. Mar Biol. 157: 991-1001.

OsSE JWM, van DEN BOOGAART JGM. 1995. Fish larvae, development, allometric growth and the aquatic environment. ICES Mar Sci Symp. 201: 21-34.

Osse JWM, van den BoogaArt JGM, van SNIK GMJ, VAN DER SLUYS L. 1997. Priorities during early growth of fish larvae. Aquaculture. 155: 249-258.

PaVlov DA. 1999. Features of transition from larva to juvenile in fishes with different types of early ontogeny. Environ Biol Fish. 56: 4152.

Pedersen BH, Nilssen EM, Huelmeland K. 1987. Variations in the content of trysin and trysinogen in larval herring (Clupea harengus) digesting copepod nauplii. Mar Biol. 94: 171181.

Potthoff T. 1984. Clearing and staining techniques. In: LAWRENCE KS, MOSER HG, RICHARDS WJ, COHEN DM, FAHAY MP, Kendall AW JR, RichardSON SL, editors. Ontogeny and systematics of fishes. Special Publication 1. American Society of Ichthyologists and Herpetologist. p. 33-37.

Rodríguez-Graña L, Vera M, Cervetto G, CAlliari DL. 2018. Trophic ecology of the White Croaker (Micropogonias furnieri Desmarest, 1823) and Rough Scad (Trachurus lathami Nichols, 1920) larvae in the Río de la Plata Estuary. In: Hoffmeyer M, Sabatini M, Brandini F, Calliari D, SantiNELLI N, editors. Plankton ecology of the Southwestern Atlantic. Cham: Springer. p. 349-371.

RoOKer JR, Holt SA. 1997. Utilization of subtropical seagrass meadows by newly settled red drum (Sciaenops ocellatus): patterns of distribution and growth. Mar Ecol Prog Ser. 158: 139-149.

SECOR HD. 2015. Migration ecology of marine fishes. Baltimore: Johns Hopkins University Press. 292 p.

SHEA BT. 1985. Bivariate and multivariate growth allometry: statistical and biological considerations. J Zool. 206: 367-390.

Simionato CG, Berasategui AD, Meccia V, Acha EM, Mianzan H. 2008. Short timescale wind forced variability in the Río de la Plata Estuary and its role on ichthyoplankton retention. Estuar Coast Shelf Sci. 76: 211-226.

SinQue C. 1980. Larvas de Sciaenidae (Teleostei) identificadas na região estuarino-lagunar de Cananéia. Universidade do São Paulo. Bol 
Zool. 5: 39-77.

SMITH PE. 1985. Year class strength and survival of 0-group clupeoids. Can J Fish Aquat Sci. 42: 69-82.

SOGARD SM. 1991. Interpretation of otolith microstructure in juvenile winter flounder (Pseudopleuronectes americanus): ontogenetic development, daily increment validation, and somatic growth relationships. Can J Fish Aquat Sci. 48: 1862-1871.

TAYLOR WR, VAN DYKE GC. 1985. Revised procedures for staining and clearing small fishes and other vertebrates for bone and cartilage study. Cibium. 9 (2): 107-119.

URHO L. 2002. Characters of larvae-what are they? Folia Zool. 51: 161-186.

WeISS G. 1981. Ictioplancton del estuario de Lagoa dos Patos, Brasil [tesis doctoral]. La Plata: Facultad de Ciencias Naturales y Museo,
Universidad Nacional de La Plata. 164 p.

WERNER RG. 2002. Habitat requeriments In: FUIMAN LA, WERNER RG, editors. Fishery Science. The unique contributions of early life stages. Oxford: Blackwell Publishing. p. 161182.

Wilson DT, McCormick MI. 1997. Spatial and temporal validation of settlement marks in the otoliths of tropical reef fishes. Mar Ecol Prog Ser. 153: 259-271.

WiLSON DT, McCORMICK MI. 1999. Microstructure of settlement-marks in the otoliths of tropical reef fishes. Mar Biol. 134: 29-41.

Xie S, Watanabe Y, Saruwatari T, Masuda R, Yamashita Y, SASSa C, Konishi Y. 2005. Growth and morphological development of sagittal otoliths of larval and early juvenile Trachurus japonicus. J Fish Biol. 66: 17041719. doi: 10.1111/j.0022-1112.2005.00717.x 


\section{APPENDIX}

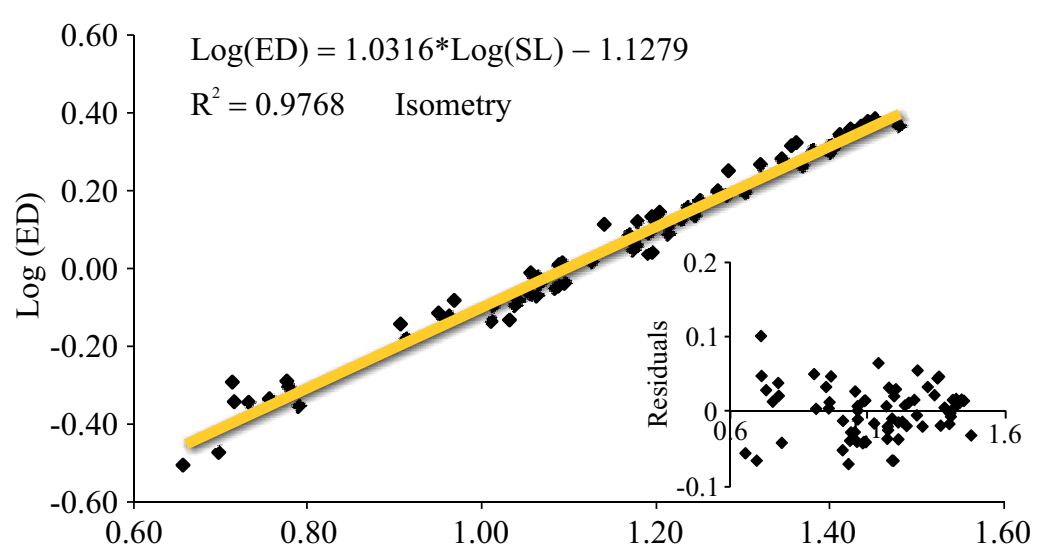

Linear regressions of log-transformed morphometric variables and residuals' charts used to identify changes in variables meaning changes in individual's shape.
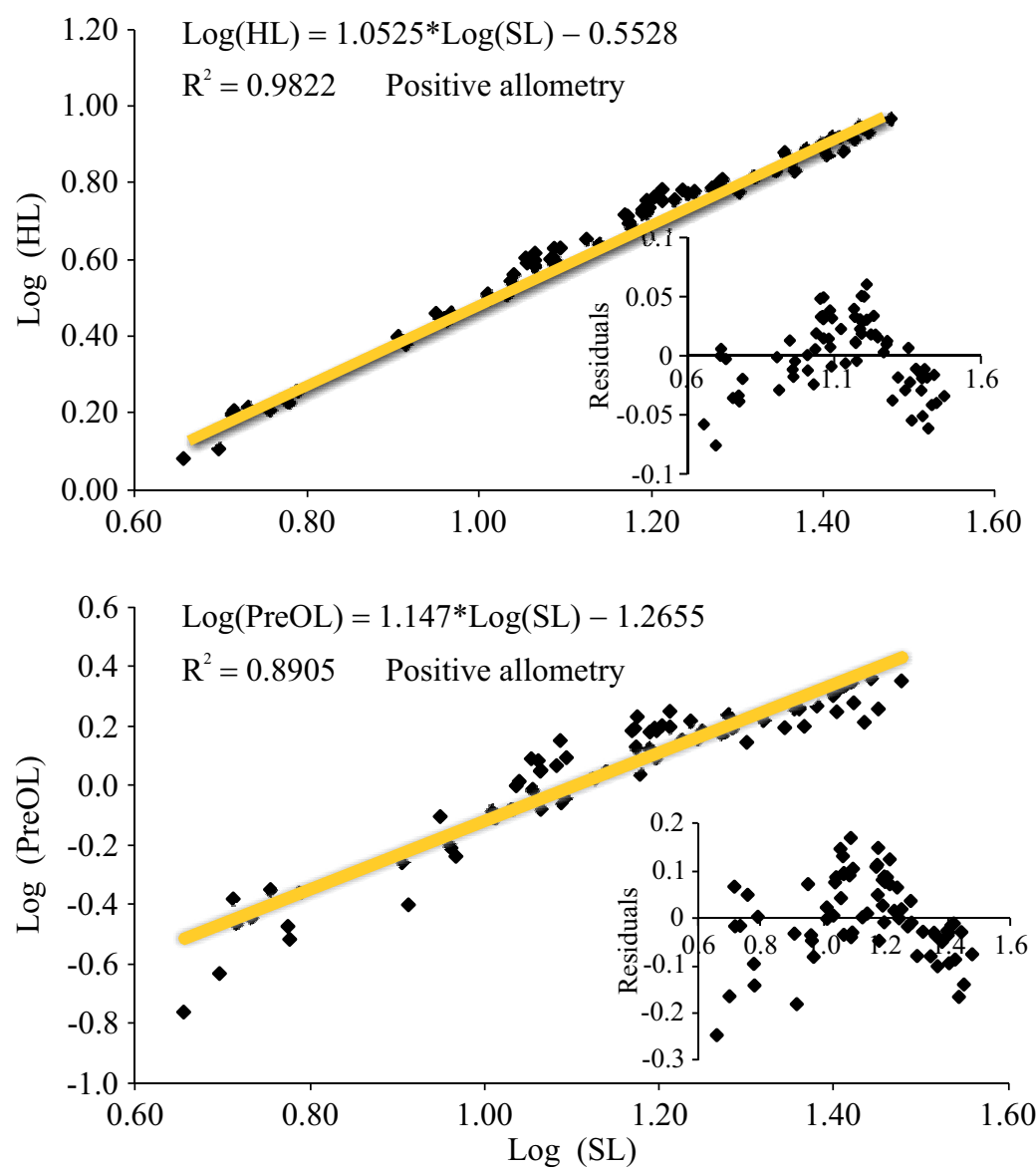
Appendix. Continued.
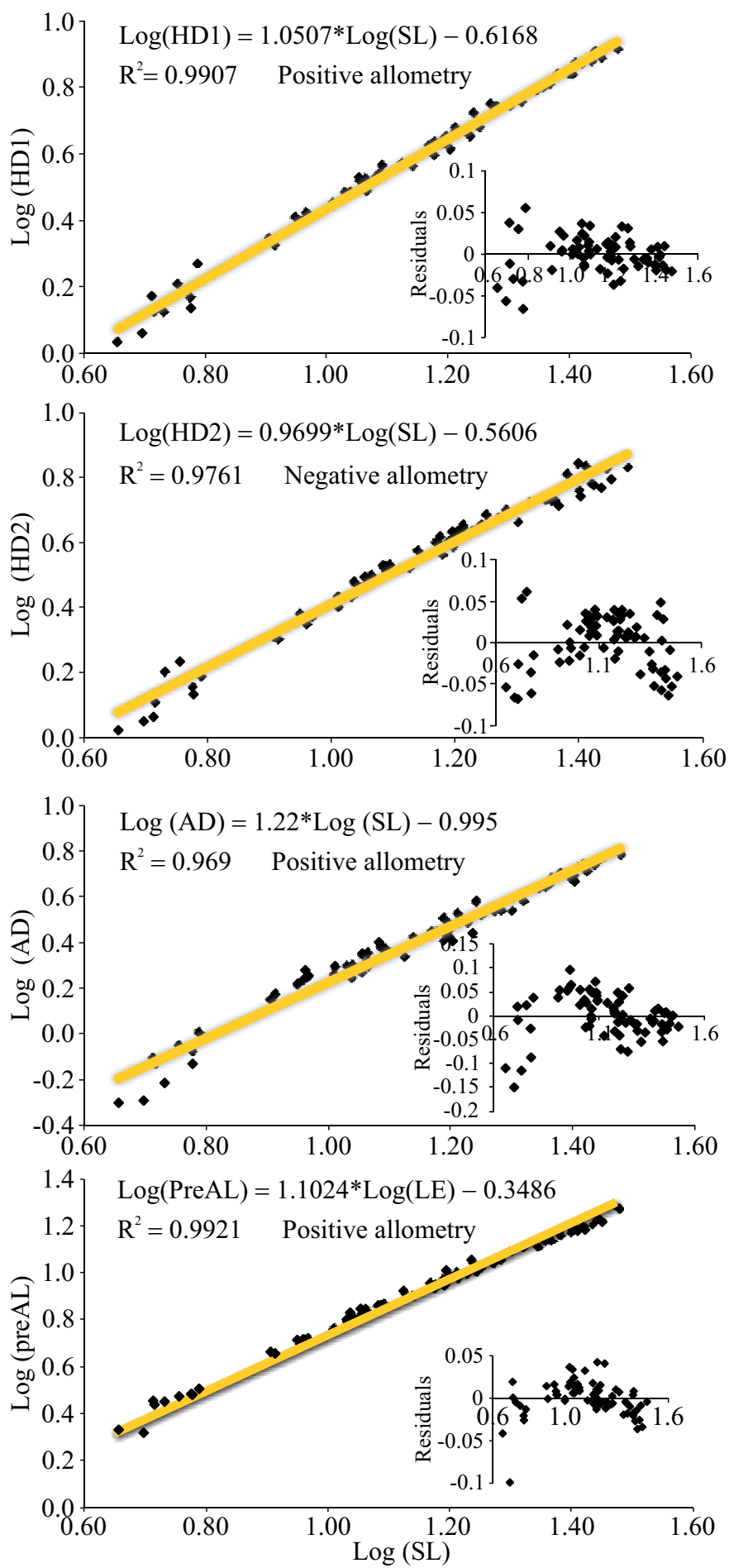
Appendix. Continued.
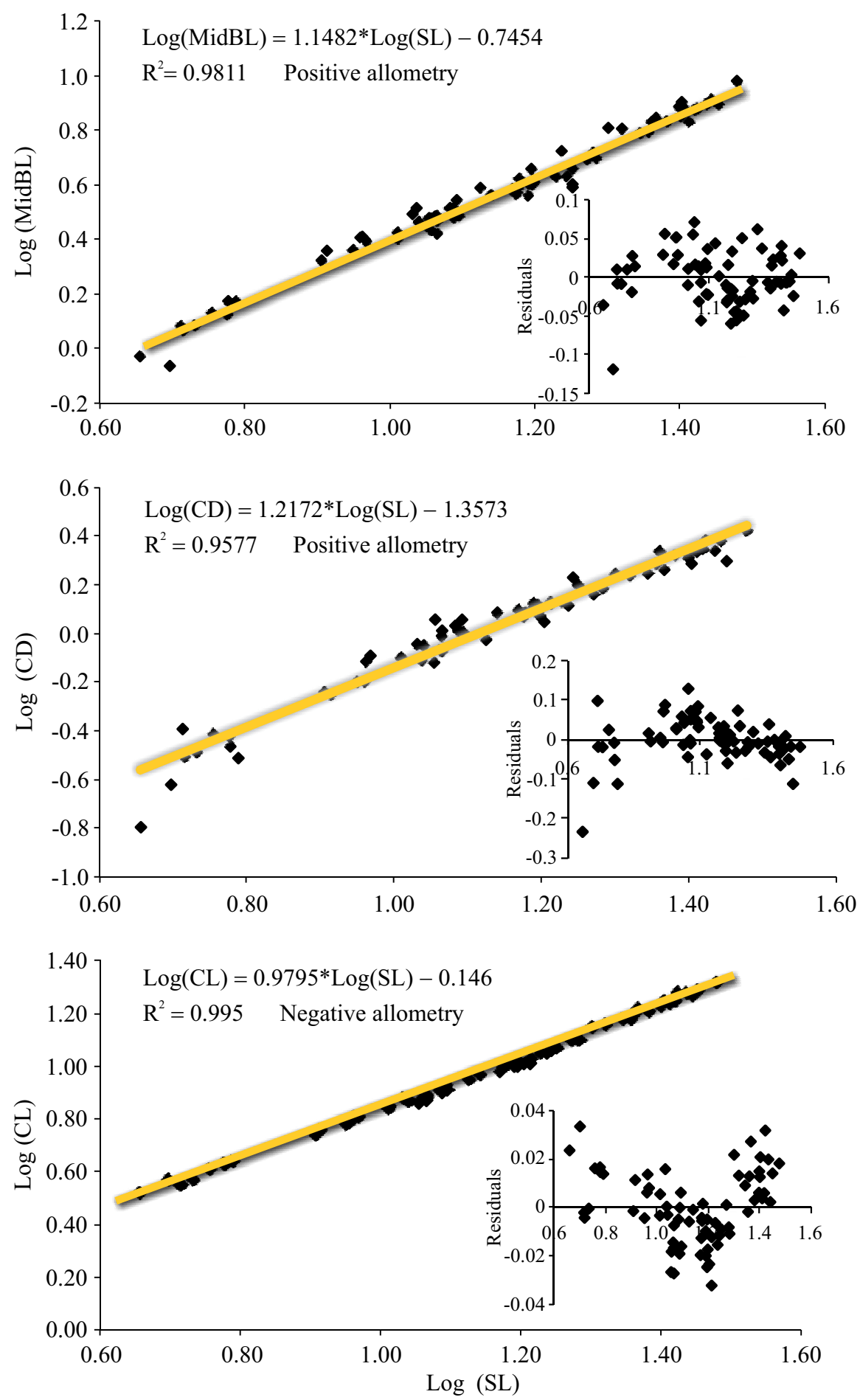